\title{
MUSCLE GLUT-4 AND INSULIN BINDING TO ERYTHROCYTES AND TO ADIPOSE, LIVER AND MUSCLE TISSUE IN GENETICALLY HYPERTENSIVE OBESE RATS AND IN THEIR LEAN SIBLINGS: EFFECT OF LONG LASTING TERGURIDE TREATMENT
}

\author{
Věroslav Golda ${ }^{1}$, Jiřina Hilgertová ${ }^{2}$, Štefan Zórad ${ }^{3}$ \\ Institute of Experimental Neurosurgery, Charles University, Faculty of Medicine and Teaching Hospital, \\ Hradec Králové; (Head: doc. MUDr. J. Náhlovský, CSc.) ${ }^{1}$ \\ Laboratory for Endocrinology and Metabolism, Charles University, Faculty of Medicine, Prague; \\ (Head: prof. MUDr. V. Schreiber, DrSc.) ${ }^{2}$ \\ Institute of Experimental Endocrinology, Slovak Academy of Sciences, Bratislava, Slovak Republic; \\ (Head: RNDr. R. Květňanský, DrSc.) ${ }^{3}$
}

Summary: Experiments were performed in the genetically hypertensive obese rats of Koletsky type (SHR/N-cp) and in their lean siblings of both sexes.Insulin binding to erythrocytes and to adipose tissue, lever tissue and muscle tissue was monitored in the control animals and in the animals under the long lasting terguride treatment. In control animals insulin binding shows substrain and tissue dependence being elevated in lean rats except insulin binding to erythrocytes where inverse is true. Terguride increases percentage of specific insulin binding to erythrocytes in all groups except obese females, terguride increases percentage of specific binding to adipose tissue except lean females, the mentioned drug remained without effect in muscle tissue in all group except lean females where drug induced elevation was detected. The effect of terguride in liver tissue was monitored only in males of both substrains, elevation was found only in lean. GLUT-4 was analyzed only in muscle tissue. The effect of terguride was found in obese females, i.e., in the group which shows reduced GLUT-4 relative to lean females.

Key words: SHR/N-cp of Koletsky type; Insulin binding to erythrocytes; Adipose tissue; Muscle tissue and liver tissue; Muscle GLUT-4; Long lasting terguride treatment

\section{Introduction}

In our previous study we documented strain dependent insulin binding to erythrocytes (5).It was found profound decrease of insulin binding in the $\mathrm{SHR} / \mathrm{N}-\mathrm{cp}$ obese rats as well as in their lean siblings relative to the normotensive rats of Wistar strain. In the other paper (3) we show alleviating effect of terguride in glucose intolerance which is done genetically in the Koletsky obese rats and in their lean siblings. Terguride is potent to alleviate hyperinsulinemia which is based genetically in obese Koletsky rats (4).

Terguride increases specific insulin binding to erythrocytes in both substrains of Koletsky rats except obese females (4). The mentioned data suggest possible causal relationship between glucose intolerance, hyperinsulinemia, and specific insulin binding to erythrocytes. Obese females represents the exception, i.e.,in this type of rats terguride induced alleviation of genetically based hyperinsulinemia and glucose intolerance is not accompanied by the changes in specific insulin binding to erythrocytes. It is substantiated looking for a possible drug induced changes in specific insulin binding in the other tissues, i.e., in adipose, muscle and liver tissue. Moreover, such experiments verified a possible different drug sensitivity of insulin independent tissue (see erythrocytes) in comparison with drug sensitivity of insulin dependent tissues (see liver, muscle, adipose tissue) (7).

Nevertheless, there remains the other possibility, i.e., it cannot be a priori excluded that terguride is potent to influence the postreceptor events. There is a reason for a monitoring of terguride influence on GLUT-4 glucose transporter. It is well-founded because Friedman et al. (1) found in the obese Koletsky rats decrease of GLUT-4.They did not mentioned sex of the animals. 


\section{Methods}

\section{Animals}

Experiments were performed in obese and lean genetically hypertensive rats of Koletsky type (6) of both sexes at the age of 3 - 4 months. Lean Koletsky rats represent dominant non-obese homozygotes and heterozygotes whereas their obese siblings are recessive homozygotes. The abnormal animals were obtained by Koletsky (6) when mating spontaneously hypertensive female rat (Okamoto-Aoki strain) with a normotensive Sprague-Dawley male rat. The genetically obese animals appeared after several generations of selective inbreeding of hypertensive off-springs of the original cross.

The blood pressure (measured by a indirect method) attained in lean genetically hypertensive males $24.61 \pm 2.22$ $\mathrm{kPa}(\mathrm{n}=15), 17.60 \pm 1.32 \mathrm{kPa}(\mathrm{n}=8)$ in females $(2)$. The obese genetically hypertensive rats show comparable blood pressure (6).

After weaning at the age of 30 days the animals were kept in groups of four and supplied with water and ST pelleted diet ad libitum. During the experiments the animals were kept in group of two in PVC boxes (humidity: $55 \pm 10 \%$, room temperature: $22 \pm 1^{\circ} \mathrm{C}$, natural lighting).

Body weight, water and pellet intake was controlled daily (except Saturdays and Sundays). Obtained differences between lean and obese Koletsky rats are comparable with the data published in our previous paper (3).

\section{Plasma insulin}

Plasma insulin was estimated by radioimmunoassay.

\section{Insulin binding to erythrocytes}

Plasma was separated from approximately $3 \mathrm{ml}$ of heparinized blood drawn by cardiac puncture. Erythrocytes were obtained in the presence of constant amount of 125Iinsulin (33pM) at $15{ }^{\circ} \mathrm{C} 3$ hours. Results were corrected for nonspecific binding. The details of the method are published previously (5).

\section{Plasma lipids}

Blood sampled by cardiac puncture (in light ether anaesthesia at 07.00 after $14 \mathrm{~h}$ starvation) was centrifugated and the serum was stored in plastic tubes at $-20{ }^{\circ} \mathrm{C}$. Total plasma triglycerides were estimated enzymatically by means of Hitachi analyzer.

\section{Glucose tolerance}

Blood was sampled to heparinized capillaries (from retrobulbar plexus under light ether anaesthesia) before glucose loading (basal glycemia) as well as 30,60,120 and $180 \mathrm{~min}$ after glucose loading. Glucose (3g/kg b.w., $30 \%$ solution) was applied intragastrically after $14 \mathrm{~h}$ starvation. Glycemia was estimated enzymatically (Oxochrom glucose Lachema). Glucose tolerance is expressed as a sum of glycemia obtained 30,60,120 and 180 min after glucose loading (,area under the glucose tolerance curve“).

\section{Isolation of epididymal fat plasma membrane}

Frozen fat tissue was homogenized by Ultraturax in buffer consisting of $50 \mathrm{mM}$ Tris- $\mathrm{HCl}, 0.25 \mathrm{M}$ Sucrose, $1 \mathrm{mM}$ phenylmethylsulfonylflouride and $1 \mathrm{mM}$ benzamoidine, $\mathrm{pH}=$ 7.4. The homogenate was filtered through four layers gauze and centrifugated at $4^{\circ} \mathrm{C}, 20 \mathrm{~min}$ at $3000 \mathrm{x} \mathrm{g}$. Obtained supernatant was further centrifugated at $200000 \mathrm{xg}$ for $15 \mathrm{~min}$. Resulted pellet represents a crude plasma membrane preparation. The pellet was resuspended in $50 \mathrm{mM}$ Tris- $\mathrm{HCl}, 1 \mathrm{mM}$ EDTA, $\mathrm{pH}=7.6$ and immediately used for binding assay. Protein content was determined using the Lowry method.

\section{Isolation of muscle plasma membranes}

Frozen m.Q.was homogenized in liquid nitrogene. Obtained powder was further homogenized in glass-teflon homogenize in the buffer consisting of $0.25 \mathrm{M}$ sucrose, 10 $\mathrm{mM}$ HEPERS, $1 \mathrm{mM}$ EDTA and $1 \mathrm{uM}$ Pepstatin, $\mathrm{pH}=7.5$. Centrifugation and the following steps are the same as above described for the fat tissue plasma membranes.

\section{Isolation of liver plasma membranes}

Frozen liver tissue is homogenized in five fold amount of buffer consisting of $0.3 \mathrm{M}$ sucrose and $0.025 \mathrm{M}$ Tris- $\mathrm{HCl}$, $\mathrm{pH}=7.6$. Centrifugation and the following steps are the same as described above.

\section{Determination of insulin specific binding}

Insulin binding to isolated plasma membranes was performed in $1.5 \mathrm{ml}$ Eppendorf tubes. The binding assay mixture contained $50 \mathrm{ug}$ of plasma membrane proteins, $100 \mathrm{ul}$ of labeled iodinated insulin ( $0.2 \mathrm{nM}$ final concentration) and a binding buffer in final volume of $0.5 \mathrm{ml}$. For fat tissue plasma membranes $0.1 \mathrm{M}$ Tris- $\mathrm{HCl}, 2 \mathrm{mM}$ N-ethylmaleimid, $1 \mathrm{mM} \mathrm{CaCl} 2,0.1 \%$ bovine serum albumin proteinase free (BSA), $\mathrm{pH}=7.6$ buffer was used. The binding buffer for muscle plasma membranes consisted of $150 \mathrm{mM} \mathrm{NaCl}$, $50 \mathrm{mM}$ HEPES, 0.1\% BSA, $100 \mathrm{uM}$ PMSF and $1 \mathrm{UM}$ Pepstatin, $\mathrm{pH}$ 7.4. For liver membranes $50 \mathrm{mM}$ Tris- $\mathrm{HCl}$, $0.2 \%$ BSA, pH 7.4 binding buffer was used. Nonspecific insulin binding was determined under the same conditions as above in the presence of 1 (for fat and liver) or 10 (for muscle) $\mathrm{uM}$ of nonlabeled insulin.Specific binding was determined as a difference between binding in absence and the presence of nonlabeled insulin.

\section{Determination of GLUT-4 in muscle}

1. Isolation of total plasma membrane fraction from frozen muscle

Frozen muscle tissue (musculus quadriceps) was stirred with a spatula in liquid nitrogen to obtain a homogenous powder. The powder was transferred into ice cold buffer (10 $\mathrm{mM}$ HEOES, $250 \mathrm{mM}$ sucrose, $20 \mathrm{mM}$ EDTA, $1 \mathrm{mM}$ PMSF and $1 \mathrm{uM}$ leupeptin, $\mathrm{pH}$ 7.5) in glass homogenizer with a teflon pestle. After homogenization the homogenate was centrifuged in cooled centrifuge $\left(4^{\circ} \mathrm{C}\right) 15 \mathrm{~min}$ at 2000 $\mathrm{x}$ g. Obtained sediment containing nuclei and cellular de- 
bris was discarded and the supernatant underwent a high speed centrifugation at $150000 \mathrm{x}$ g for $90 \mathrm{~min}$. Resulted pellet was designed as total plasma membrane preparation. The pellet was resuspended in $50 \mathrm{mM}$ Tris- $\mathrm{HCl}$ buffer,pH 7.4 and the aliquod of the suspension was used for determination of protein concentration.

2. Electrophoresis of plasma membranes and immunoblotting of GLUT-4.

Fresh total membrane preparation was solubilized with the Laemmli sample buffer $(1: 1)$ at $37^{\circ} \mathrm{C}$ for $30 \mathrm{~min}$. The solubilized membranes were separated on a $12 \%$ polyacrylamide gel electrophoresis using a Bio-Rad Mini-Protein gel apparatus.Protein were then electrotransferred from the gel to nitrocellulose membrane (HYBOND, Amersham, USA) at $100 \mathrm{~V}$ for 1 hour using a Bio-Rad Mini Trans-Blot apparatus. The membranes were blocked with $5 \%$ nonfat dry milk in $50 \mathrm{mM}$ Tris- $\mathrm{HCl}, 2 \mathrm{mM} \mathrm{CaCl}, 80 \mathrm{mM} \mathrm{NaCl}, \mathrm{pH} 8$ for 1 hour at room temperature. After blocking the membranes were incubated overnight at $4 \mathrm{C}$ with rabbit anti-GLUT-4 antibody (Charles River Pharmservices, USA) diluted 1:500 with blocking solution. The solution of the antibody was discarded and the membranes were washed $4 \times 10 \mathrm{~min}$ with TEN buffer ( $50 \mathrm{mM}$ Tris-HCl, $5 \mathrm{mM}$ EDTA, $150 \mathrm{mM} \mathrm{NaCl}$, $\mathrm{pH}$ 7.4) containing $0.05 \%$ Tween 20 followed by 3 x $10 \mathrm{~min}$ wash PBS.At the end of final wash the membranes were incubated with secondary antibody linked to horseradish peroxidase (anti-rabbit IgG, PIERCE, USA) in PBS with $0.05 \%$ Tween 20 for 1 hour at room temperature. Finally the membranes were washed with PBS-Tween ( 5 x $10 \mathrm{~min})$ and deionized water $(3 \times 5 \mathrm{~min})$. The protein bands containing GLUT-4 were vizualized by exposing the membranes to enhanced chemiluminescence reagent according to manufacturer's instructions (Amersham, USA). Autoradiography was carried out using Hyperfilm ECL (Amersham, USA). The specific band intensities were quantitated by optic densitometry using Kodak DS DC40 camera and ID Image Analysis Software (Eastman Kodak, USA). The results are expressed in arbitrary units of signal intensity.

\section{Terguride treatment}

The drug was applied i.p. in two daily doses (70.00 and 14.00) for 21 days (when lipemia was investigated) or for 11 days only (when glucose tolerance was monitored). Terguride maleate was administered at a dose of $0.1 \mathrm{mg} / \mathrm{kg}, 0.1 \mathrm{mg}$ of terguride maleate was dissolved in $1 \mathrm{ml}$ of water pro injectione. Solution of drug was applied at the dose $1 \mathrm{ml} / \mathrm{kg}$ b.w.

\section{Statistics}

The data were analyzed by Student t-test to determine terguride effect in individual groups and individual parameters.

\section{Results}

\section{Insulin binding to erythrocytes (Table l)}

In control animals obese females shows higher insulin binding to erythrocytes than lean females.
When considering terguride effect on the insulin binding to erythrocytes there is increase in all group except obese females.

Table I: Insulin binding to erythrocytes

\begin{tabular}{|l|c|c|c|}
\hline Group & Control & Terguride & P \\
\hline SHR-M & $2.05 \pm 0.92(6)$ & $3.19 \pm 0.68(8)$ & 0.01 \\
\hline SHR-F & $1.89 \pm 0.53(7)$ & $2.66 \pm 0.57(7)$ & 0.01 \\
\hline SHR-O-M & $3.54 \pm 2.30(15)$ & $10.32 \pm 7.05(15)$ & 0.01 \\
\hline SH-O-F & $2.62 \pm 1.31(16)^{\mathrm{B}}$ & $3.13 \pm 1.83(12)$ & n.s. \\
\hline
\end{tabular}

Table 1: Means \pm SD. Specific insulin binding to erythrocytes. Abbreviations: SHR - lean genetically hypertensive Koletsky rats, SHR-O - obese genetically hypertensive Koletsky rats, M - males, F females, number in bracketts $=$ number of animals per group Statistical evaluation: differences between control and terguride treated animals is evaluated at the right side, differences between control male and female of lean as well as obese rats is expressed by small letters, differences between lean and obese rats is expressed by capital: a or $\mathrm{A}-\mathrm{P}<0.10$, b or $\mathrm{B}-\mathrm{P}<0.05, \mathrm{c}$ or $\mathrm{C}-\mathrm{P}<0.02$, $\mathrm{d}$ or $\mathrm{D}-\mathrm{P}<0.01$.

Insulin binding to adipose tissue (Table 2)

In control animals obese males as well as females show lower insulin binding than lean males and females.

Terguride elevates insulin binding to erythrocytes in obese males as well as females and in lean males.

Table 2: Insulin binding to adipose tissue

\begin{tabular}{|l|c|c|c|c|}
\hline Group & $\mathrm{n}$ & Control & Terguride & $\mathrm{P}$ \\
\hline SHR-M & 7 & $4.27 \pm 0.83$ & $3.30 \pm 0.68$ & 0.01 \\
\hline SHR-F & 6 & $4.13 \pm 0.14$ & $4.05 \pm 0.38$ & n.s. \\
\hline SHR-O-M & 8 & $1.74 \pm 0.36^{\mathrm{D}}$ & $2.09 \pm 0.42$ & 0.05 \\
\hline SHR-O-F & 6 & $1.76 \pm 0.29^{\mathrm{D}}$ & $2.19 \pm 0.37$ & 0.02 \\
\hline
\end{tabular}

Table 2: Means \pm SD of insulin binding to adipose tissue.

Abbreviations: $\mathrm{n}$ - number of animals per group, the other abbreviations are the same as in Table 1.

\section{Insulin binding to muscle tissue (Table 3)}

In control animals obese males shows lower insulin binding to muscle tissue than lean males.In lean animals there is apparent sex dependence in the level of insulin binding to muscle tissue, i.e., being higher in males.

Terguride increases insulin binding to muscle tissue only in lean females.

Table 3: Insulin binding to muscle tissue

\begin{tabular}{|l|c|l|l|c|}
\hline Group & $\mathrm{n}$ & \multicolumn{1}{|c|}{ Control } & Terguride & $\mathrm{P}$ \\
\hline SHR-M & 7 & $0.76 \pm 0.11$ & $0.79 \pm 0.10$ & n.s. \\
\hline SHR-F & 7 & $0.59 \pm 0.15^{\mathrm{c}}$ & $0.89 \pm 0.26(5)$ & 0.02 \\
\hline SHR-O-M & 7 & $0.59 \pm 0.14^{\mathrm{D}}$ & $0.68 \pm 0.20$ & n.s. \\
\hline SHR-O-F & 6 & $0.59 \pm 0.13$ & $0.53 \pm 0.19(5)$ & n.s. \\
\hline
\end{tabular}

Table 3: Means \pm SD Insulin binding to muscle tussue.Abbreviations are the same as in Table 1. 


\section{Insulin binding to liver tissue (Table 4)}

Insulin binding to liver tissue was not yet measured in females rats.In the males we obtained following results.

In control animals lean males show higher insulin binding to liver tissue than obese males.

Terguride increases insulin binding to liver tissue in lean males.

Table 4: Specific insulin binding to liver tissue

\begin{tabular}{|l|c|c|c|c|}
\hline Group & $\mathrm{n}$ & Control & Terguride & $\mathrm{P}$ \\
\hline SHR-M & 6 & $11.19 \pm 1.10$ & $13.60 \pm 0.72$ & 0.01 \\
\hline SHR-O-M & 6 & $9.17 \pm 1.16^{\mathrm{D}}$ & $10.00 \pm 2.29$ & n.s. \\
\hline
\end{tabular}

Table 4: Means \pm SD. Specific binding to liver tissue. Abbreviations are the same as in Table 1.

\section{GLUT4 in the muscle tissue (Table 5)}

The immunoblots of GLUT-4 were monitored by two individual films, one was used in females and the second one in males.For the technical reasons it was not possible to use only one film. There is a ground for impossibility to analyze sex dependence.

In control animals obese females show lower GLUT-4 than lean females. There is no difference between lean and obese males.

Terguride elevated GLUT-4 in obese females and remained without effect in the males of both substrains.

Table 5: GLUT-4 in the muscle tissue

\begin{tabular}{|l|c|c|c|c|}
\hline Group & $\mathrm{n}$ & Control & Terguride & $\mathrm{P}$ \\
\hline SHR-M & 5 & $31.6 \pm 3.1$ & $32.0 \pm 1.1$ & n.s. \\
\hline SHR-F & 5 & $57.6 \pm 3.0$ & $62.8 \pm 4.7$ & n.s. \\
\hline SHR-O-M & 5 & $36.4 \pm 3.9$ & $37.6 \pm 4.3$ & n.s. \\
\hline SHR-O-F & 5 & $37.2 \pm 3.0^{\mathrm{D}}$ & $79.8 \pm 6.4$ & 0.01 \\
\hline
\end{tabular}

Table 5: Means \pm SD.Values are in relative densitometric units. Abbreviation: D - P $<0.01$ (control lean females versus control obese females).

Fig. I: Autoradiogram of GLUT-4
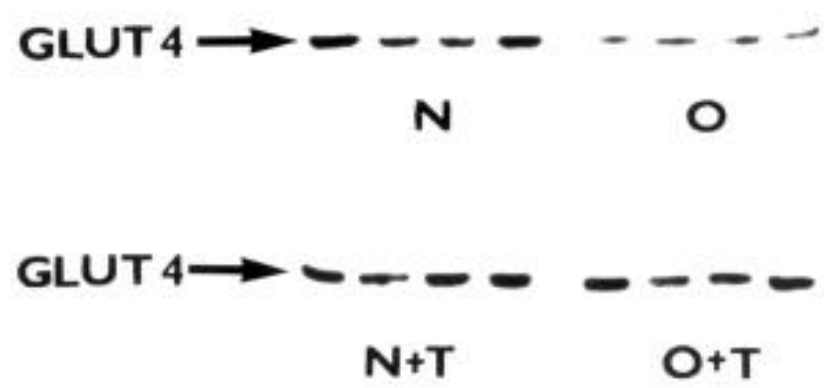

The space for photo of a repersentative autoradiogram of GLUT-4

Fig. 1: A representative autoradiogram of GLUT-4 protein levels in muscle total membranes of female rats. Abbraviations: $\mathrm{N}$ - nonobese animals, $\mathrm{O}$ - obese animals, $\mathrm{N}+\mathrm{T}$-nonobese animals treated with terguride, $\mathrm{O}+\mathrm{T}$ - obese animals treated with terguride.

\section{Basal glycemia (Table 6 and 7)}

In control animals basal glycemia shows sexdependence, in lean being lower in females and substrain difference being lower in males of obese rats obese. Terguirde decreases glycemia in males of both substrains. At the level of trend $(\mathrm{P}<0.10)$ there is elevation in lean females.

Table 6: Effect of long term terguride treatment on the parameters of glycide metabolism

\begin{tabular}{|l|c|c|c|}
\hline variables & drug & SHR-M & SHR-F \\
\hline basal glycemia & Co & $5.47 \pm 0.59(7)$ & $4.65 \pm 0.67(8)^{3}$ \\
(mmol/l) & Te & $4.92 \pm 0.51(8)^{\mathrm{b}}$ & $5.05 \pm 0.51(8)^{\mathrm{a}}$ \\
\hline insulinemia & Co & $243 \pm 77(7)$ & $203 \pm 68(8)$ \\
(pmol/1) & Te & $179 \pm 49(8)^{\mathrm{b}}$ & $169 \pm 2 \pm(8)^{\mathrm{a}}$ \\
\hline glucose & Co & $29.3 \pm 2.1(7)$ & $29.8 \pm 0.3(8)$ \\
tolerance & Te & $26.6 \pm 2.9(8)^{\mathrm{b}}$ & $27 . \pm \pm 1.8(8)^{\mathrm{c}}$ \\
(mmol/l) & & & \\
\hline
\end{tabular}

Table 6: Means \pm SD. Effect of long lasting terguride treatment on parameters of glycide metabolism. Abbreviations:

number in bracketts - number of animals in group, a $-\mathrm{P}<0.10, \mathrm{~b}$ $\mathrm{P}<0.05$, c - $\mathrm{P}<0.02$, d - $\mathrm{P}<0.01$ : significance of terguride effect,significances between controls obese versus controls lean is labeled by capital (A,B,C,D), significance between control males and control females is labeled 1,2,3,4.Co -control animals, Te - animals treated by terguride. The other abbrevations are the same as in Table 1.

\section{Insulinemia (Table 6 and 7)}

In control animals insulinemia shows sex dependence, in obese rats being increased in males and substrain dependence being increased in obese of both sexes.

Insulinemia is decreased by terguride in all groups of rats, but the decrease is at the level of trend $(\mathrm{P}<0.10)$ in lean females and in obese males.

\section{Glucose tolerance (Table 6 and 7)}

In control animals sex dependence is expressed in obese rats, area under the curve being decreased in females and substrain dependence - area under the curve is elevated in both sexes of obese rats.

Terguride decrease the area under the curve in all groups of rats.

Table 7: Effect of long lasting terguride treatment on parameters of glycide metabolism

\begin{tabular}{|l|c|c|c|}
\hline variables & drug & SHR-M & SHR-F \\
\hline basal glycemia & Co & $4.43 \pm 0.80(13)$ & $4.68 \pm 0.84(13)$ \\
(mmol/1) & Te & $3.99 \pm 0.74(12)$ & $4.06 \pm 0.80(12)^{\mathrm{b}}$ \\
\hline insulinemia & $\mathrm{Co}$ & $861 \pm 452(13)^{\mathrm{D}}$ & $537 \pm 283(13)^{\mathrm{D} 3}$ \\
(pmol/1) & $\mathrm{Te}$ & $630 \pm 225(12)^{\mathrm{a}}$ & $364 \pm 138(12)^{\mathrm{b}}$ \\
\hline glucose & $\mathrm{Co}$ & $41.4 \pm 10.9(13)^{\mathrm{D}}$ & $35.6 \pm 7.9(13)^{\mathrm{D} 3}$ \\
tolerance & $\mathrm{Te}$ & $29.0 \pm 2.4(12)^{\mathrm{d}}$ & $24.7 \pm 2.5(12)^{\mathrm{d}}$ \\
(mmol/l) & & & \\
\hline
\end{tabular}

Table 7: Means $\pm \mathrm{SD}$. Effect of long lasting terguride treatment on parameters of glycide metabolism. Abbreviation are the same as in Table 1 and Table 6. 


\section{Discussion}

In the discussion we want to pay an attenttion not only to the effect of terguride in the insulin binding to the different tissues but it will be valuable to take notice of insulin binding in the control animals as well.

Thus it cannot be omitted substrain differences in the insulin binding to the different tissues. Considering erythrocytes obese females show higher insulin binding than the lean females. In the other tissues inverse is true, i.e., in obese animals the insulin binding is lower than in lean animals. It is so in both sexes in adipose tissue, in the males in muscle tissue. Till now in liver tissue we measured insulin binding only in the males. It was again elevated in lean animals.

The decreased insulin binding to adipose, muscle and liver tissue in the genetically hypertensive obese Koletsky rats is accompanied by hyperinsulinemia (compare the data in Table 6 and 7). Thus the decrease of insulin binding in adipose, muscle and liver tissue can be judged as an expression of down regulation. It is known (8) that hyperinsulinemia per se induced the decrease of insulin receptors. There remained open question why it is not so in insulin binding to erythrocytes. To what extent it can be considered as consequence of the functional characteristic of different tissues (on one side erythrocytes as insulin insensitive tissue, and on the other side adipose, muscle and liver as an insulin sensitive tissues) (7), it remained to be solved.

The above mentioned tissue dependence in the substrain differences in the level of insulin binding is not expressed in the terguride effect on the insulin binding. It is apparent that terguride shows its effect in both types of tissue, i.e., in the insulin sensitive and in insulin insensitive as well. When the effect of terguride is expressed in the changes of insulin binding, then in every case it is increased. We have never found decrease.

Considering the terguride sex and substrain dependence, then minimal dependence is expressed in insulin binding to erythrocytes and to adipose tissue.In other words, in both cases terguride is potent to eleviate insulin binding in three groups of four. Inverse is true for a muscle tissue where terguride was potent to eleviate insulin binding only in one group of animals, i.e., in the lean females.

Interesting data we obtained when GLUT-4 was measured in muscle tissue.The elevation of the mentioned glucose transporter was found only in obese females.In this type of animals terguride alleviates hyperinsulinemia but shows no effect on insulin binding to muscle tissue. Moreover, terguride alleviates in obese females genetically based glucose intolerance. These data suggest that GLUT-4 can take part in the regulative mechanism of insulinemia as well as in glucose tolerance.

In control animals insulin binding shows tissue and substrain dependence being elevated in lean rats except insulin binding to erythrocytes where the inverse is true. At the same time insulinemia shows substrain differences being elevated in obese animals. Thus the decrease of insulin binding to adipose, liver and muscle tissue can be considered as an expression of down regulation. At recent time is difficult to explain why in the insulin binding to erythrocytes opposite can be found, i.e., insulin binding is lower in lean rats (Table 1 , females). It cannot be a priori exclude that it is done by the category of tissue,i.e., erythrocytes do not belong to insulin sensitive tissues (7).

Obtained data suggest that terguride is potent to decrease the genetically based hyperinsulinemia and glucose intolerance.It is accompanied (or induced ?) by the elevation of insulin binding to tissues and in obese females GLUT-4 can take part in the alleviation of above mentioned abnormalities.

As to the GLUT-4 in control obese females our findings are directly comparable with results obtained by Friedman et al. (1).They found that GLUT-4 protein was reduced by $25 \%$ in the muscle of the obese compared with lean rats. The ancestor of our rats and the rats which analysed by Friedman et al. (1) are the same, i.e., SHR female and Sprague-Dawley male.As in our rats a close self-sustaining colony has been maintained by brother-sister mating for more than 20 years. Lean rats represent dominant non-obese homozygotes and heterozygotes whereas their obese siblings are recesssive homozygotes. The mentioned authors did not mentioned the sex of obese rats in which they found decreased GLUT-4 in muscle relative to lean rats.

The authors compared insulin receptor proteins in skeletal muscle (1). They found decrease in obese rats relative to lean rats. Again, the sex of animals is not mentioned. This findings is comparable with our males where we found lower insulin binding in muscle of obese rats relative to lean rats.

\section{Acknowledgement}

This paper was supported by Internal Grant Agency of Ministry of Health of the Czech Republic No 3684-3. The authors wish to thank Carl T.Hansen, Animal Genetics Division, National Institute of Health, Bethesda, USA, for providing the genetically hypertensive rats of Koletsky type, and GALENA, Czech Republic for providing terguride maleate.The authors also wish to thank The etical commission of Medical Faculty of Charles University, Hradec Králové, for kind approving with the project of Grant 3684-3.

\section{References}

1. Friedman JE, Ishizuka T, Liu S, Farrell CJ, Bedol D, Koletsky RJ, Kaaug HL, Ernsberger P. Reduced insulin receptor signaling in the obese spontaneously hypertensive Koletsky rat. Am J Physiol 1997;273:E1014-23.

2. Golda V, Petr R. Dopaminergic mechanism and genetic factor in blood pressure regulation. Suppl Sb Ved Pr Lek Fak Univerzity Karlovy Hradec Králové 1988;25:419-27.

3. Golda V, Cvak L. Terguride but not bromocriptine alleviated glucose abnormalities and hyperlipidemia in obese 
and lean genetically hypertensive Koletsky rats. Physiol Res 1994;43:299-305.

4. Golda V, Hilgertová J. Multiple regression analysis of parameters of lipide and glycide metabolism in obese and lean genetically hypertensive Koletsky rats under long lasting terguride treatment. Acta Med (Hradec Králové) 1996:39:141-8. 5. Hilgertová J, Kummel L, Hovorka R, Golda V. Decreased insulin binding and internalization in hepatocytes and erythrocytes of SHR Koletsky rats depend on the presence of „f" gene and on sex. Metabolic characteristics of hepatocytes from obese rats. In: Insulin and the cell membrane. I Klimeš, BV Hovard,RC Kahn (eds), London:Harwood academic publishers, 1989:81-92.

6. Koletsky S. Pathologic findings and laboratory data in a new strain of obese hypertensive rats. Am J Pathol 1975;80:1975.
7. Pelikánová T. Insulin resistance and non-insulin-dependent diabetes mellitus. Int Med 1995;41:99-103 (in Czech). 8. Šebeková E, Klimeš I, Štolba P. Cellular and molecular mechanisms of insulin resistance. Int Med 1995;41:76-83 (in Czech).

Submitted May 1998.

Accepted June 1998.

Doc. MUDr. PhDr. Věroslav Golda, CSc., Institute of Experimental Neurosurgery, Charles University, Faculty of Medicine and Teaching Hospital, 50005 Hradec Králové, Czech Republic. 